American Journal of Applied Sciences 6 (3): 484-491, 2009

ISSN 1546-9239

(C) 2009 Science Publications

\title{
Diatrizoate, Iopromide and Iotrolan Enhanced Cytotoxicity of Daunorubicin in Multidrug Resistant K562/adr Cells: Impaired the Mitochondrial and Inhibited the P-Glycoprotein Function
}

\author{
${ }^{1}$ Nitaya Snitwongse Na Ayudhya and ${ }^{2}$ Samlee Mankhetkorn \\ ${ }^{1}$ Department of Radiology, Sappasitthiprasong Hospital, Ubonratchatani, 34000 Thailand \\ ${ }^{2}$ Laboratory of Physical Chemistry, Molecular and Cellular Biology; Center of Excellence for Molecular \\ Imaging, Department of Radiologic Technology, Faculty of Associated Medical Sciences, \\ Chiang Mai University, Chiang Mai 50200 Thailand
}

\begin{abstract}
Multidrug resistance was an obstacle in cancer chemotherapy because the cells decreased their intracellular drug accumulation by energy-dependent compounds efflux pumps such as Pglycoprotein (P-gp). This study observed some iodinated radiographic contrast media, diatrizoate, iopromide and iotrolan affected the cellular energetic state and the kinetics of P-gp in drug-sensitive K562 and drug resistant K562/adr cell lines using spectrophotometer and spectrofluorometer. By colorimetric MTT assay, it was found that contrast media $(0-3500 \mu \mathrm{M})$ had no effect on both K562 and K562/adr cell viabilities, but in co-treatment with daunorubicin (DNR), diatrizoate decreased cell viability in $\mathrm{K} 562 / \mathrm{adr}$ cells by decreasing $\mathrm{IC}_{\mathrm{so}}$ of DNR from $610.7 \pm 74.5 \mathrm{nM}$ to $360 \pm 108.9 \mathrm{nM}$. The change in cellular energetic state was studied using rhodamine B as a probe to estimate mitochondrial membrane potential $\left(\Delta \Psi_{\mathrm{m}}\right)$. The results showed that $3500 \mu \mathrm{M}$ diatrizoate decreased $\Delta \Psi_{\mathrm{m}}$ from $162.2 \pm 0.3 \mathrm{mV}$ to $86.9 \pm 9.9 \mathrm{mV}$ in K562/adr cells. The kinetics of P-gp-mediated efflux of DNR could be reduced by diatrizoate from 0 (no inhibition) to $0.65 \pm 0.11$. This inhibition could be partially prevented in co-incubation with $20 \mathrm{nM}$ concanamycin A or $10 \mu \mathrm{M}$ cytochalasin B. Among the three molecules, diatrizoate showed the best efficiency. It could be proposed for further studies that diatrizoate could be used as MDR identification or MDR imaging and also acted as MDR sensitizing agent in cancer treatments.
\end{abstract}

Key words: Contrast media, Multi Drug-Resistance (MDR), mitochondrial membrane potential $\left(\Delta \Psi_{\mathrm{m}}\right)$, P-glycoprotein-mediated efflux

\section{INTRODUCTION}

Iodinated radiographic contrast media are used in clinical practice as diagnostic pharmaceuticals to indicate the site and size of pathology, including cancer staging. The most widely used contrast media are water soluble, fully substituted, triiodinated benzoic acid derivatives. They are commonly classified according to two characteristics, ionic versus non ionic and monomer versus dimer ${ }^{[1]}$. Tolerability of modern contrast media is very high that the huge amount (up to $100-200 \mathrm{~g}$ in total number) of drug can be injected as a bolus with a side effect coincidence of less than $5 \%{ }^{[2]}$. However, the administered contrast media into blood vessels (about 1-2 $\mathrm{mI} \mathrm{kg}^{-1}, \sim 300 \mathrm{mg}$ of iodine per milliliter, 600-1500 mOsm) generated a concentration- dependent effect on neutrophils. In particular, ionic contrast media dramatically decreased in the mitochondrial membrane potential $\left(\Delta \Psi_{\mathrm{m}}\right)$ of neutrophils, affecting the membrane permeability that would allow the anion portion to actually penetrate into the cells ${ }^{[3]}$. The same effects of contrast media on mitochondrial activity and on reduction of ATP level in LLC-PK1 and HRPTE cells were reported ${ }^{[4]}$. Moreover, some radiographic contrast media such as iohexol, a monomer-non ionic contrast medium affect MRP2- and P-gp-mediated transport of Fluorescein-Methotrexate (FL-MTX) and a fluorescent cyclosporine derivative (NBD-CSA) in intact killifish renal proximal tubules ${ }^{[5]}$. However, the direct effects of contrast media on the MDR transporters such as P-glycoprotein and MRP1 did not study yet. Such activities of these hyperdensity

Corresponding Author: Samlee Mankhetkorn, Laboratory of Physical Chemistry, Molecular and Cellular Biology; Center of Excellence for Molecular Imaging, Department of Radiologic Technology, Faculty of Associated Medical Sciences, Chiang Mai University 50200, Thailand Tel: 6653-949305 Fax: 66-053-949305 
molecules could be clearly demonstrated by using multidrug-resistant cancer cell lines.

In this study, the erythromyelogenous leukemic K562 and its P-glycoprotein overexpression K562/adr cells were used for investigating the effects of contrast media on the function of P-glycoprotein and the mitochondrial function. All the contrast media used affected the cellular energetic state only in MDR cells by decreasing in $\Delta \Psi_{\mathrm{m}}$ and in the P-glycoprotein function leading to the restoration of intracellular daunorubicin concentration consequently the cyotoxicity was increased in the drug-resistant cells. The results provide a new possible application of contrast media other than usual utilization. The combination with appropriate mitochondrial probe that accumulated in the cells depending on $\Delta \Psi_{\mathrm{m}}$, the contrast media could be used as a mitochondrial energetic state modulator that was specific to MDR cells.

\section{MATERIALS AND METHODS}

Drugs and Chemicals: Adriamycin (Dox) and daunorubicin (DNR) were kindly provided by Professor Arlette Garnier-Suillerot, Laboratoire de Chimie Physique Biomoleculaire et Cellulaire, UFR Sante Medicine et Biologie Humaine, Bobigny, Université de Paris Nord, France. Iodinated radiographic contrast media, diatrizoate (Angiografin, Schering AG, Germany), iopromide (Ultravist, Schering AG, Germany) and iotrolan (Isovist, Schering $A G$, Germany) were kindly provided by Department of Radiology, Sappasitthiprasong Hospital, Ubonratchatani, Thailand. Rhodamine $\mathrm{B}$ and tetrazolium salt (3-(4,5-dimethyl-2-thiazolyl)-2,5diphenyl-2H-tetrazolium bromide (MTT) were from Amresco. Concanamycin A and cytochalasin B were from Sigma Chemical Co.

Deionized double distilled water was used throughout the experiments for solutions and buffers. Stock solutions of adriamycin (Dox) and daunorubicin (DNR) were prepared in water just before use and their concentrations were determined by UV-Visible Spectrophotometer, using a molar extinction coefficient of $11500 \mathrm{M}^{-1} \mathrm{~cm}^{-1}$ at $480 \mathrm{~nm}^{[6]}$. The dilutions of contrast media (diatrizoate, iopromide and iotrolan) were freshly prepared before used in water from known concentrations of these compounds in the commercially available solutions, stated in the manufacturer's information. Stock solution of MTT was prepared by dissolving $5 \mathrm{mg}$ MTT $\mathrm{mL}^{-1}(12 \mathrm{mM})$ in HEPES-Na ${ }^{+}$ buffer and filtered through a $0.22 \mu \mathrm{m}$ filter then stored at $4^{\circ} \mathrm{C}$. A stock solution of cytochalasin $\mathrm{B}$ was prepared in DMSO (dimethyl sulphoxide) and stored at less than $\left(-20^{\circ} \mathrm{C}\right)$. The absorption spectra were recorded on a Hewlett Packard G1103A spectrophotometer and the fluorescence spectra were recorded on a Perkin Elmer LS 50 B spectrofluorometer.

Cell lines and cell culture conditions: The adriamycin-sensitive erythromylogenous leukemic cell line, K562 and its P-glycoprotein-overexpressing K562/adr cells ${ }^{[6,7]}$ were kindly provided by Professor Arlette Garnier-Suillerot, Laboratoire de Chimie Physique Biomoleculaire et Cellulaire, UFR Sante Medicine et Biologie Humaine, Bobigny, Université de Paris Nord, France. These cells were routinely cultured in RPMI 1640 medium supplemented with $1 \%$ penicillin-streptomycin (Sigma Chemical Co.) and 10\% fetal bovine serum (Gibco Biocult Ltd.) at $37^{\circ} \mathrm{C}$ in a humidified incubator at $95 \%$ air and $5 \% \mathrm{CO}_{2}$. The resistant K562/adr cells were cultured with $100 \mathrm{nM}$ doxorubicin two weeks before the experiments. The cultures were initiated at a density of $1 \times 10^{5}$ cells $\mathrm{mL}^{-1}$, grew exponentially to about $8-10 \times 10^{5}$ cells $\mathrm{mL}^{-1}$ in 3 days. For the assays, the cultures were initiated at $5 \times 10^{5}$ cells $\mathrm{mL}^{-1}$ to have cells in the exponential growth phase and were used $24 \mathrm{~h}$ later after reaching a density of approximately $8-10 \times 10^{5}$ cells $\mathrm{mL}^{-1}$. Cell viability was assessed by Trypan blue exclusion. The number of cells was determined by a haemocytometer.

Cytotoxicity assay: The viability of cells was determined using colorimetric MTT- reduction assay with some modification ${ }^{[7,8]}$. Briefly, cells $\left(5 \times 10^{4}\right.$ cells $\mathrm{mL}^{-1}$ ) were incubated in RPMI-1640 medium supplemented with $10 \%$ fetal bovine serum in the presence of various concentrations of contrast media (diatrizoate, iopromide, or iotrolan) at $37^{\circ} \mathrm{C}$ in a humidified incubator with $95 \%$ air and $5 \% \mathrm{CO}_{2}$. After $72 \mathrm{~h}, 2 \mathrm{mM}$ final concentration MTT was added to the cell suspension and then further incubated for $4 \mathrm{~h}$. The concentration of daunorubicin and pirarubicin required to inhibit cell proliferation by $50 \%$ when measured at $72 \mathrm{~h}\left(\mathrm{IC}_{50}\right)$ was determined by plotting the percentage of cell growth inhibition versus drug concentration. The Resistance Factor (RF) was defined as the $\mathrm{IC}_{50}$ of resistant cells divided by the $\mathrm{IC}_{50}$ of sensitive cells and was equal to 40 .

Co-treatment of daunorubicin and contrast media: Cells $\left(5 \times 10^{4}\right.$ cells $\left.\mathrm{mL}^{-1}\right)$ were incubated in RPMI-1640 medium supplemented with $10 \%$ fetal bovine serum in the presence of various concentrations of daunorubicin and a fixed concentration of $0.5,2.0$ and $3.5 \mathrm{mM}$ contrast media (diatrizoate, iopromide, or iotrolan). The 
experiments were performed and calculated using colorimetric MTT- reduction assay as described previously. The efficacy of contrast media $(\delta)$ in increasing the efficacy of daunorubicin was obtained by the following equation:

$$
\delta=\left[\mathrm{IC}_{50(\mathrm{R})}-\mathrm{IC}_{50(\mathrm{RCM})}\right] /\left[\mathrm{IC}_{50(\mathrm{R})}-\mathrm{IC}_{50(\mathrm{~S})}\right]
$$

where $\mathrm{IC}_{50(\mathrm{R})}$ was the concentration of daunorubicin that inhibited $50 \%$ of MDR cell growth, $\mathrm{IC}_{50(\mathrm{RCM})}$ was the concentration of drug that inhibited $50 \%$ of MDR cell growth in the presence of contrast media and $\mathrm{IC}_{50(\mathrm{~S})}$ is the concentration of drug that inhibited $50 \%$ of drugsensitive cell growth ${ }^{[9]}$.

The $\delta$ was equal to 0 when the MDR cells were treated with daunorubicin alone and $\delta$ was equal to 1 when the contrast media reverse $100 \%$ of the MDR phenotype resulting in the same $\mathrm{IC}_{50(\mathrm{RCM})}$ as that of drug sensitive cell line.

The effect of contrast media on mitochondrial membrane potential $\left(\Delta \Psi_{\mathrm{m}}\right)$ : The mitochondrial membrane potential $\left(\Delta \Psi_{\mathrm{m}}\right)$ was measured using a noninvasive functional study ${ }^{[10]}$, which can be used to determine and to monitor a spontaneous change in mitochondrial functions in drug-sensitive and drugresistant cells. Cells $\left(2 \times 10^{6}\right.$ cells $)$ were incubated with various concentrations of contrast media, diatrizoate, iopromide and iotrolan in $2 \mathrm{~mL}$ of HEPES- $\mathrm{Na}^{+}$buffer with $40 \mathrm{nM}$ rhodamine $\mathrm{B}$ in $1 \mathrm{~cm}$ quartz cuvette and vigorously stirred at $37^{\circ} \mathrm{C}$. The rhodamine $\mathrm{B}$ fluorescence intensity (F) at $582 \mathrm{~nm}$ (excited at 553 $\mathrm{nm}$ ) was monitored as a function of time. The addition of $200 \mu \mathrm{M}$ MTT were performed within $10 \mathrm{~min}$ of incubation, yielding a progressive decrease in rhodamine B fluorescence intensity. The estimation of $\Delta \Psi_{\mathrm{m}}$ was done using Nernst equation: $\mathrm{C}_{\mathrm{m}}^{\circ} / \mathrm{C}^{\circ}{ }_{\mathrm{i}}$ $=10^{(\Delta \Psi \mathrm{mF} / 2.303 \mathrm{RT})}$ and $\Delta \Psi_{\mathrm{m}}=-61.51 \log \mathrm{V}_{\mathrm{i}}-258.46$, where $\Delta \Psi_{\mathrm{m}}$ is the mitochondrial membrane potential in $\mathrm{mV}$, $\mathrm{RT} / \mathrm{F}$ is $26 \mathrm{mV}$ at $37^{\circ} \mathrm{C}, \mathrm{C}^{\circ}{ }_{i}$ is $40 \mathrm{nM}$ and $\mathrm{V}_{\mathrm{i}}$ is in nM.s ${ }^{-1}$.

Modulation of kinetics of the p-glycoproteinmediated efflux of daunorubicin by contrast media: Cells $\left(2 \times 10^{6}\right.$ cells $)$ were incubated in $2 \mathrm{~mL} \mathrm{HEPES-K^{+ }}$ buffer in the absence of glucose under continuous stirring at $37{ }^{\circ} \mathrm{C}$ in $1-\mathrm{cm}$ quartz cuvette. The extracellular $\mathrm{pH}\left(\mathrm{pH}_{\mathrm{e}}\right)$ of 7.25 was chosen all the experiments to be equal to the $\mathrm{pH}$ of cytoplasm since the cytosolic $\mathrm{pH}$ in $\mathrm{K} 562 / \mathrm{adr}$ cells was shown to be within the range of 7.2-7.3 $3^{[11]}$. Initially, the cells were depleted energy by adding $10 \mathrm{mM} \mathrm{NaN}_{3}$, an inhibitor of cytochrome oxidase in mitochondrial electron transport chain for $30 \mathrm{~min}$, leading to depletion of ATP in these cells about $90 \%$. The cells remained viable throughout the experiment as checked by trypan blue exclusion. Daunorubicin (DNR) was added to cell suspension at concentration of $1 \mu \mathrm{M}$. The fluorescence intensity of $\mathrm{DNR}$ at $590 \mathrm{~nm}$ (excited at $480 \mathrm{~nm}$ ) was spectrofluorometrically followed as a function of time. A decrease in fluorescence intensity was observed during incubation with cells, due to quenching of fluorescence after the intercalation of DNR between the base pairs of DNA. At the first steady state, the intracellular free drug concentration $C_{i}^{\prime}$ was equal to the free drug concentration in the extracellular medium $\left(\mathrm{C}_{\mathrm{e}}\right)$ when $\mathrm{pH}_{\mathrm{i}}$ equals $\mathrm{pH}_{\mathrm{e}}$. Then $5 \mathrm{mM}$ glucose was added at $\mathrm{t}=\mathrm{t}_{\mathrm{glu}}$, after the sequential addition of various concentrations of contrast media resulting in an increasing the fluorescence intensity at $590 \mathrm{~nm}$. The slope of the tangent to the curve was $(\mathrm{dF} / \mathrm{dt})$ tglu and the kinetics of release of DNR $\left(\mathrm{V}_{\mathrm{a}}\right)$ was: $\mathrm{V}_{\mathrm{a}}=(\mathrm{dF} / \mathrm{dt})_{\text {tglu }}$. $\left(\mathrm{C}_{\mathrm{T}} / \mathrm{F}_{0}\right)$ in $\mu \mathrm{M} . \mathrm{s}^{-1}$. The mean rate constant $\left(\mathrm{k}_{\mathrm{a}}\right)$ of $\mathrm{P}-$ glycoprotein- mediated can be written as: $\mathrm{k}_{\mathrm{a}}=\mathrm{V}_{\mathrm{a}} / \mathrm{n}\left(\left(\mathrm{C}_{\mathrm{T}}\right.\right.$ $\left.-C_{n}^{\prime}\right)$ in $s^{-1}$. The ability of contrast media to inhibit the P-glycoprotein active efflux of a drug can be determined using the ratio of $\mathrm{k}_{\mathrm{a}}^{\mathrm{i}} / \mathrm{k}_{\mathrm{a}}^{0}$ where $\mathrm{k}_{\mathrm{a}}^{\mathrm{i}}$ and $\mathrm{k}_{\mathrm{a}}^{0}$ were stand for the P-glycoprotein -mediated efflux coefficient in the presence and in the absence of contrast media, respectively. When $\mathrm{k}_{\mathrm{a}}^{\mathrm{i}} / \mathrm{k}_{\mathrm{a}}^{0}$ is equal to 1 that means there is no inhibition of active efflux and to 0 means the P-glycoprotein active efflux is completely blocked.

\section{RESULTS AND DISCUSSION}

Enhancement of daunorubicin cytotoxicity: All contrast media studied at the concentrations up to 3.5 $\mathrm{mM}$ did not inhibit the cell growth of both K562 and K562/adr cell line. Contrary to daunorubicin, an anticancer drug belongs to anthracycline family, $\mathrm{IC}_{50}$ value is $17.5 \pm 0.1 \mathrm{nM}$ for $\mathrm{K} 562$ and $610 \pm 74 \mathrm{nM}$ for K562/adr cells. It was clear that the co-treatment using daunorubicin and various concentration of diatrizoate, iopromide or iotrolan $(0.5,2.0$ and $3.5 \mathrm{mM})$ did not affect the $\mathrm{IC}_{50}$ of daunorubicin in drug-sensitive K562 cells. However, these compounds increased the efficacy of daunorubicin when similar conditions of series of experiments were performed with drug-resistant K562/adr cells (Fig. 1). The capabilities of 0.5, 2.0 and $3.5 \mathrm{mM}$ diatrizoate in increasing the efficacy of DNR ( $\delta$ ) were $0.11,0.17$ and 0.45 , respectively. 


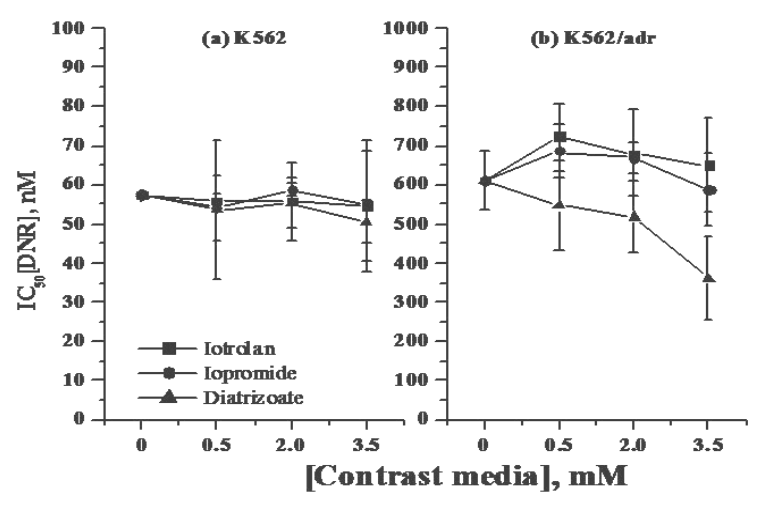

Fig. 1: Concentration of daunorubicin required to inhibit cell growth by $50 \%\left(\mathrm{IC}_{50}\right)$ in the presence of contrast media; iotrolan ( $\boldsymbol{\square})$, iopromide $(\bullet)$, and diatrizoate $(\boldsymbol{\Delta})$ in (a) K562 cell line and (b) K562/adr cell line. Cells $\left(5 \times 10^{4}\right.$ cells $\left.\mathrm{mL}^{-1}\right)$ were incubated with various concentrations of daunorubicin and a fixed concentration of contrast media $(0.5,2.0$ or $3.5 \mathrm{mM})$ in 24 -well plates at $37^{\circ} \mathrm{C}$ for $72 \mathrm{~h}$. The cells were harvested after 4-hour of $2 \mathrm{mM}$ MTT incubation. The formazan was spectrophotometically measured at $560 \mathrm{~nm}$. Each value is the mean $\pm \mathrm{SD}$ of three independent experiments

Inhibition of the P-glycoprotein- mediated efflux of daunorubicin by contrast media: The effects of contrast media on the P-glycoprotein function could be determined by monitoring the efficiency of protein mediated efflux of daunorubicin in the absence and presence of contrast media. The $\mathrm{k}_{\mathrm{a}}$ of daunorubicin in the absence of contrast media was equal to $0.67 \pm 0.06$ $\mathrm{pL}$. cell $\mathrm{I} \mathrm{Sec}^{-1}$. The efficacy of contrast media that can inhibit the function of P-glycoprotein in the presence of $0.5,2.0$ and $3.5 \mathrm{mM}$ of diatrizoate, iopromide or iotrolan were indicated in Fig. 2.

In fact, the contrast media are hyperdensity molecules that affected the cellular morphology, which could be easily observed by light microscope. Cell shrinkage was immediately occurred after contrast media addition to the cells and then they returned to normal morphology in a short time. This phenomenon could affect various cellular physiologies of cells such as acidification of the $\mathrm{pH}_{\mathrm{i}}$ then followed by a correction of volume then $\mathrm{pH}_{\mathrm{i}}$, leading to modifications in protein synthesis ${ }^{[12]}$ and particularly, the change in membrane conformation could influence the function of P-gp.

In order to verify the direct interaction of contrast media on P-gp, two series of experiments were performed. The first set of experiments, the P-

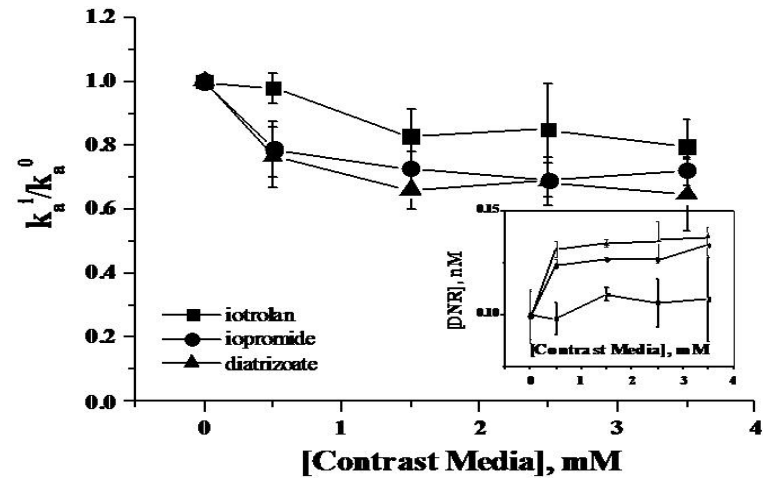

Fig. 2: Ratio of the mean P-gp-mediated efflux of daunorubicin in the presence to the absence of iotrolan $(\boldsymbol{\square})$, iopromide $(\bullet)$ or diatrizoate $(\boldsymbol{\Delta})$ in K562/adr cell line. The experiments were performed by following the fluorescence intensity of $1 \mu \mathrm{M}$ DNR $\left(\lambda_{\mathrm{ex}}=480 \mathrm{~nm}, \lambda_{\mathrm{em}}=590\right.$ $\mathrm{nm})$ in $2 \times 10^{6}$ cells in $2 \mathrm{~mL}$ HEPES K ${ }^{+}$buffer, $\mathrm{pH}$ 7.25 at $37^{\circ} \mathrm{C}$, which were depleted energy by adding $10 \mathrm{mM} \quad \mathrm{NaN}_{3} \quad 30 \mathrm{~min}$ before daunorubicin addition. After the first steady state, $5 \mathrm{mM}$ glucose was added before addition of contrast media then the active efflux coefficient of P-gp $\left(k_{a}\right)$ was measured. Each value represents the mean $\pm \mathrm{SD}$ of three independent experiments. Inset The overall cellular accumulation of daunorubicin in $\mathrm{K} 562 / \mathrm{adr}$ cells in the absence or presence of iotrolan ( $\boldsymbol{\square})$, iopromide $(\bullet)$ and diatrizoate $(\boldsymbol{\Delta})$ at various concentrations

glycoprotein-mediated efflux of daunorubicin was measured in the MDR cells after treated using $10 \mu \mathrm{M}$ cytochalacin B for $24 \mathrm{~h}$ in the presence or absence of contrast media. Furthermore, using cytochalasin B, a chemical that inhibits polymerization of F-actin, that is one of important mechanisms of endocytosis or fixing the membrane movements ${ }^{[13,14]}$. The second set of experiments, the P-glycoprotein-mediated efflux of daunorubicin was measured in the MDR cells after treated using $20 \mathrm{nM}$ concanamycin A for 10 minutes. Concanamycin A was used to inhibit the action of vacular $\mathrm{H}^{+}$-translocating ATPases that presence at the lysosomal membrane but did not inhibit the Pglycoprotein mediated-efflux of $\operatorname{drugs}^{[15,16]}$. Indeed, these conditions of experiments would protect the contrast media uptake by MDR cells. Figure 3a clearly showed that there was an increase in the Pglycoprotein-mediated efflux of daunorubicin in the presence of $3.5 \mathrm{mM}$ diazoate. Similar results were obtained when the series of experiments with similar 

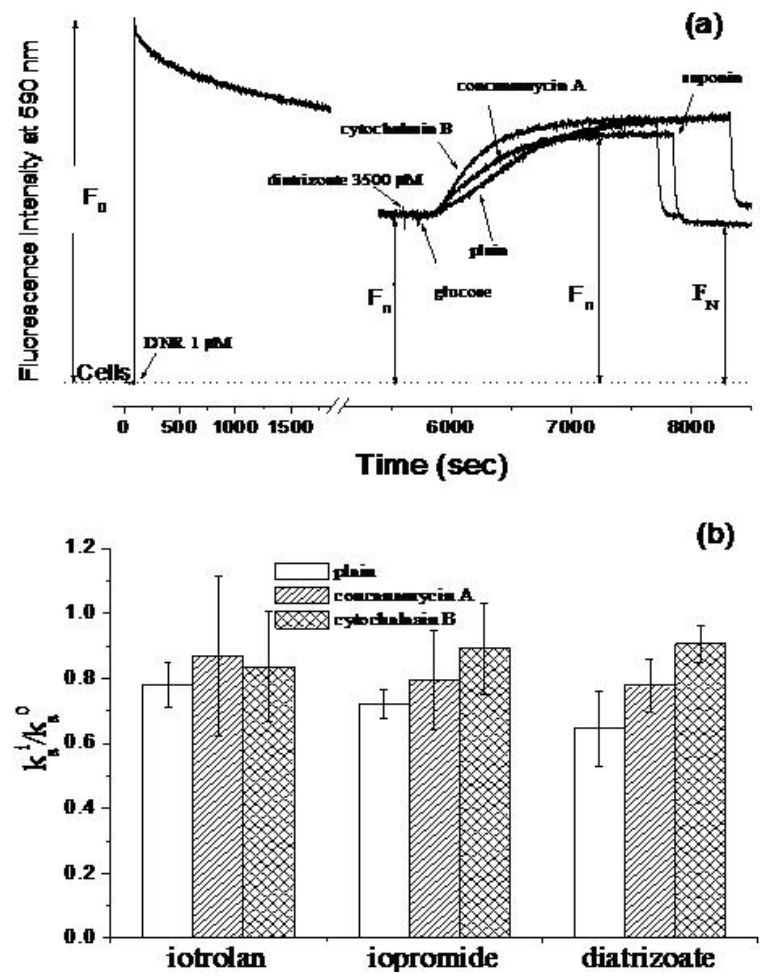

Fig. 3: Effects of $20 \mathrm{nM}$ concanamycin $\mathrm{A}$, or $10 \mu \mathrm{M}$ cytochalasin B on P-gp-mediated efflux in K562/adr cells, which was modulated by 3.5 $\mathrm{mM}$ contrast media, (a) the kinetic studies in the presence of diatrizoate without and with $20 \mathrm{nM}$ concanamycin A or $10 \mu \mathrm{M}$ cytochalasin $\mathrm{B}$, and (b) $\mathrm{k}_{\mathrm{a}}^{\mathrm{i}} / \mathrm{k}_{\mathrm{a}}{ }^{0}$ in the presence of CM without $(\square)$ and with $20 \mathrm{nM}$ concanamycin $\mathrm{A}(\mathbb{Z})$ or $10 \mu \mathrm{M}$ cytochalasin B $(\mathbb{Q})$. Each value is the mean \pm SD of three independent experiments

conditions were performed using iopromide or iotrolan. Figure $3 \mathrm{~b}$ demonstrates that an increase in the ratio of $\mathrm{k}_{\mathrm{a}}^{\mathrm{i}} / \mathrm{k}_{\mathrm{a}}{ }^{0}$ of the series of experiments with treatment with non-treatment $(\mathrm{p}<0.05)$.

The effect of contrast media on mitochondrial membrane potential $\left(\Delta \Psi_{\mathrm{m}}\right)$ : The uptake of contrast media by cells would be caused an additional consumption of ATP which can be resulted in a depletion of cellular ATP contents which is insufficient to assure the P-glycoprotein function. These impaired cellular energetic state can directly studied by measuring the mitochondrial membrane potential $\left(\Delta \Psi_{\mathrm{m}}\right)$. The $\Delta \Psi_{\mathrm{m}}$ values determined for K562 and drugresistant K562/adr cells were $166.2 \pm 5.7 \mathrm{mV}$ and $162.2 \pm 0.3 \mathrm{mV}$, respectively. It was found that among

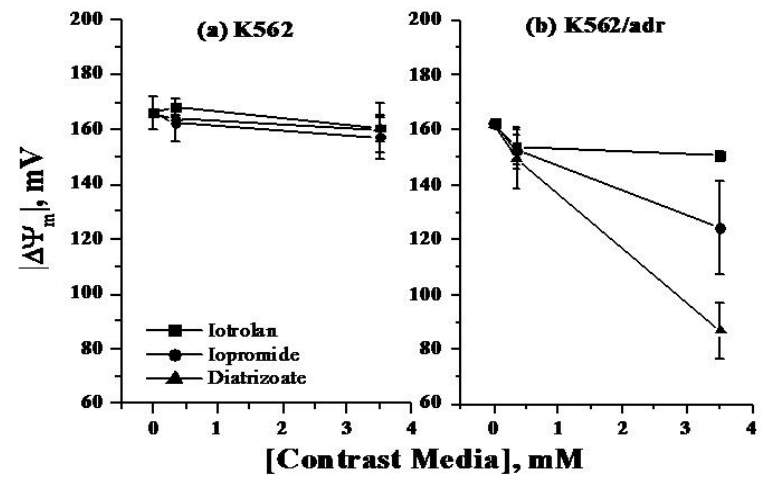

Fig. 4: Variation of the absolute values of the mitochondrial membrane potential $\left(\Delta \Psi_{\mathrm{m}}\right)$ in intact cells (a) K562 and (b) K562/adr in the presence of iotrolan ( $\boldsymbol{\square})$, iopromide $(\bullet)$ and diatrizoate $(\boldsymbol{\Delta})$ at concentration of 0,350 and $3500 \mu \mathrm{M}$. Each value is the mean $\pm \mathrm{SD}$ of three independent experiments

the contrast media used, diatrizoate $(0.35,3.5 \mathrm{mM})$ that apparently decreased $\Delta \Psi_{\mathrm{m}}$ in K562/adr cells, whereas iopromide could do with less efficiency and iotrolan was the least to do. Otherwise, in K562 cell line, there were no differences between treated cells and control (Fig. 4).

The iodinated radiographic contrast media used in this study included diatrizoate (an ionic monomer), iopromide (a non-ionic monomer) and iotrolan (a nonionic dimer). These molecules are intravenously administered in patients undergo Intravenous Pyelography (IVP) or computed tomography, which are the standard imaging modalities used to radiologically stage some cancers ${ }^{[17]}$. The cytotoxicity of contrast media was determined by the cell growth inhibition dose $\left(\mathrm{IC}_{50}\right)$. At the concentrations used in the experiments, they did not affect the cell proliferation of K562 and its corresponding MDR cell line. These concentrations were comparable to and did not overexceed the concentration administered in clinical uses (the average clinical concentration in blood circulation after IV. injection is about $2.5 \mathrm{mgI} \mathrm{mL} \mathrm{L}^{-1}$, dose recommended by Schering AG, $1 \mathrm{~mL}$ of $300 \mathrm{mgI} \mathrm{mL}^{-1}$ of contrast media per $1 \mathrm{~kg}$ body weight, whereas concentrations in this study are $0.15-2.66 \mathrm{mgI} \mathrm{mL}^{-1}$.). Although the contrast media themselves at the concentrations used in this study were not toxic to the cells, they (especially diatrizoate, an ionic monomer) were found, in co-treatment with daunorubicin, to enhance the efficiency of this anti-cancer drug to inhibit cell proliferation in the resistant K562/adr cell line. It 
means that contrast media affected the function of Pglycoprotein, which was an active drug efflux transporter in this MDR cell line, therefore increasing the cytotoxicity of daunorubicin.

The study on the change of cellular energetic state was done by following the change in mitochondrial membrane potential $\left(\Delta \Psi_{\mathrm{m}}\right)$ of drug-sensitive and drugresistant cells using rhodamine $\mathrm{B}$. The mitochondrial membrane potential is essential for the production of ATP via oxidative phosphorylation. In situ, it is a sensitive indicator for the energetic state of the mitochondria and cells. It should be noted that even a slight decrease in the $\Delta \Psi_{\mathrm{m}}$ could affect the cellular energetic state ${ }^{[9,10]}$. Indeed, the three molecules of contrast media were able to decrease $\Delta \Psi_{\mathrm{m}}$ in drugresistant K562/adr cells, but not in drug sensitive K562 cells, with different degree. The aptitude to induce a decrease in $\Delta \Psi_{\mathrm{m}}$ could be obviously seen in diatrizoate at high concentration, thus this reduced intracellular ATP. This was reasonably supported by the findings in literatures ${ }^{[18,19]}$ that intracellular ATP could be reduced following the exposure of diatrizoate in animal kidney cells, which were also expressed some drug transporters such as MRP2 and P-gp ${ }^{[5]}$. However, the co-incubation with contrast media did not affect the cytotoxicity of daunorubicin in drug-sensitive K562 cells, in comparison with drug-resistant K562/adr cells, which need more ATP to assure their ATPase activity of protein membrane transporter, i.e. P-glycoprotein. The function of P-glycoprotein was lessened resulting in an increase in intracellular cytotoxic agent, leading to MDR cell death ${ }^{[20]}$.

In vitro and in vivo MDR cell imaging is of uppermost importance for successful cancer chemotherapy. In this work, it was demonstrated that diatrizoate could probably be used as modulator of $\Delta \Psi_{\mathrm{m}}$ in combination with some mitochondrial probes such as, for in vitro studies, $\mathrm{DiOC}_{6}, \mathrm{JC}-1^{[21,22]}$ and rhodamine derivatives ${ }^{[10]}$ and for in vivo studies, ${ }^{99 \mathrm{~m}} \mathrm{Tc}-$ sestamibi ${ }^{[23]}$. With an appropriate choice of probe, this modulation could be employed to distinguish the MDR cells or even to make the image of MDR cells, because only the MDR cells, herein K562/adr, would be affected by diatrizoate. This is the case, for example, of ${ }^{99 \mathrm{~m}} \mathrm{Tc}$ - sestamibi, the $\gamma$-emitting probe that was administered in patients for localizing and imaging cancer in diagnostic nuclear medicine. Upon addition of diatrizoate, the chemo-resistant cancer cells would be recognized in low profile compared to the responsive cells.

The efficacies of diatrizoate, iopromide and iotrolan to inhibit the P-glycoprotein-mediated daunorubicin efflux in MDR cells were as well observed. This work had investigated the aptitude of these contrast media to inhibit the P-glycoproteinmediated efflux by following the uptake of daunorubicin by K562/adr cells, demonstrated with the ratio $\mathrm{k}_{\mathrm{a}}^{\mathrm{i}} / \mathrm{k}_{\mathrm{a}}{ }^{0}$ as a function of contrast medium concentration added. Among the three molecules, diatrizoate had the highest capacity to inhibit the Pglycoprotein-mediated efflux. Furthermore, this was confirmed by treating experimental MDR cells with concanamycin A and cytochalasin B. Since the active binding sites of protein membrane transporter, Pglycoprotein, were located intracellularly, any molecules or compounds that regulated P-glycoprotein had to do from inside of the cell. Considerately, the physicochemical properties of contrast media determined (unpublished data) and referred to in literatures ${ }^{[24,25]}$, diatriziate, iopromide and iotrolan could uptake into cells by endocytosis where molecules were engulfed and retained in vacuoles, which represented a part of lysosomal compartment ${ }^{[24]}$. Concanamycin A was used to inhibit the action of vacuolar $\mathrm{H}^{+}$-translocating ATPases that presented on membrane of lysosome, but did not inhibit the Pglycoprotein-mediated efflux of drug ${ }^{[15]}$. In addition, cytochalasin B was used to inhibit a wide variety of cellular movements that is one of important mechanisms of endocytosis by interacting with microfilaments in the cells ${ }^{[13]}$. These two compounds prevented contrast media to get inside the cell, leading to higher capability of P-glycoprotein-mediated efflux, when compared with the conditions that contrast media were added alone. The efficacy of contrast media, especially diatrizoate, to impair the function of P-gp seemed very apparent but the mechanism(s) of this modulation still was not clear whether they were substrates of P-gp or they affected the energy consumption of P-gp as mentioned above.

In general, most studies have focused on the effects of contrast media on kidney cells since they were excreted by nephron units after intravenous administration into patients. This is the first study to show that they also affected cellular energetic state and the function of P-glycoprotein in MDR cancer cells.

\section{CONCLUSION}

The iodinated radiographic contrast media in diagnostic radiography, diatrizoate (an ionic monomer), iopromide (a nonionic monomer) and iotrolan (a non ionic dimer) were relatively low cytotoxicity at the concentrations used that was comparable to the dosage administered in clinics. However, in the co-treatment 
with daunorubicin, an anticancer drug that was a substrate of P-glycoprotein, diatrizoate could enhance the efficacy of this anticancer drug in K562/adr cells. All the contrast media used affected the cellular energetic state only in MDR cells by decreasing $\Delta \Psi_{\mathrm{m}}$ and inhibit P-glycoprotein function, leading to the restoration of intracellular drug concentration, consequently, the cytotoxicity was increased in the drug-resistant cells. The results provide a new possible application of contrast media other than usual utilization. In combination with appropriate mitochondrial probe that accumulated in the cells depending on $\Delta \Psi_{\mathrm{m}}$, the contrast media could be used as a mitochondrial energetic state modulator that was specific to MDR cells (K562/adr cells). This study had led to some points of view that diatrizoate might be raised for further study as MDR identification in MDR imaging in vitro or in vivo with the help of some probes that their main target were in mitochondria and, eventually, a MDR chemo-sensitizing agent in cancer treatment.

\section{REFERENCES}

1. Moris, T.W., 1993. X-ray contrast media: Where are we now and where are we going? Radiology, 188: 11-16. PMID: 8511283.

2. Krause, W., 1999. Delivery of diagnostic agents in computed tomography. Adv. Drug Deliver Rev., 37: 159-173. PMID: 10837733.

3. Fanning, N.F., B.J. Manning, J. Buckley and H.P. Redmond, 2002. Iodinated contrast media induce neutrophil apoptosis through a mitochondrial and caspase mediated pathway. Br. J. Radiol., 75: 861-873. PMID: 12466250.

4. Hardiek, K., R.E. Katholi, V. Ramkumar and C. Deitrick, 2001. Proximal tubule cell response to radiographic contrast media. Am. J. Physiol-Renal, 280: F61-70. PMID: 11133515.

5. Masereeuw, R., S.A., Terlouw, R.A. van Aubel, F.G. Russel and D.S. Miller, 2000. Endothelin B receptor-mediated regulation of ATP-driven drug secretion in renal proximal tubule. Mol. Pharmacol., 57: 59-67. PMID: 10617679.

6. Mankhetkorn, S., F. Dubru, J. Hesschenbrouck, M. Fiallo and A. Garnier-Suillerot, 1996. Relation among the resistance factor, kinetics of uptake and kinetics of the P-glycoprotein-mediated efflux of doxorubicin, daunorubicin, 8-(S)-fluoroidarubicin and idarubicin, multidrug resistant K562 cells. Mol. Pharmacol., 49: 532-539. PMID: 8643093.
7. Meesungneon, J., J. Jay-Gerin and S. Mankhetkorn, 2002. Relation between MDR1 mRNA levels, resistance factor and the efficacy of P-glycoprotein-mediated efflux of pirarubicin in multidrug resistant K562 sublines. Can. J. Physiol. Pharm., 80: 1054-1063. PMID: 12489924.

8. Twentyman, P.R. and M. Luscombe, 1987. A study of some variables in a tetrazolium dye (MTT) based assay for cell growth and chemosensitivity. Br. J. Cancer, 56: 279-285. PMID: 3663476.

9. Reungpatthanapong, P. and S. Mankhetkorn, 2002. Modulation of multidrug resistance by artemisinin, artesunate and dihydroartemisimin in K562/adr and GLC4/adr resistant cell lines. Biol. Pharm. Bull., 25: 1555-1561. PMID: 12499639

10. Reungpatthanaphong, P., S. Dechsupa, J. Meesungnoen, C. Loetchutinat and S. Mankhetkorn, 2003. Rhodamine B as a mitochondrial probe for measurement and monitoring of mitochondrialmembrane potential in drug-sensitive and -resistant cells. J. Biochem. Bioph. Meth., 57: 1-16. PMID: 12834959.

11. Frezard, F. and A. Garnier-Suillerot, 1991. Determination of the osmotic active drug concentration in the cytoplasm of anthracyclineresistant and sensitive K562 cells. Biochim. Biophys. Acta, 1091: 29-35. PMID: 1995065.

12. Dascalu, A. and A. Peer, 1994. Effects of radiological contrast media on human endothelial and kidney cell lines: Intracellular $\mathrm{PH}$ and cytotoxicity. Acad. Radiol., 1: 145-150. PMID: 9419478

13. Lin, S. and J.A. Spudich, 1974. Biochemical studies on the mode of action of cytochalasin B. Cytochalasin B binding to red cell membrane in relation to glucose transport. J. Biol. Chem., 249: 5778-5783. PMID: 4412199.

14. Sokolov, I., S. Iyer and CD. Woodworth, 2006. Recovery of elasticity of aged human epithelial cells in vitro. Nanomedicine, 2: 31-36. DOI: 10.1016/j.nano.2005.12.002.

15. Loetchutinat, C., W. Priebe and A. GarnierSuillerot, 2001. Drug sequestration in cytoplasmic organelles does not contribute to the diminished sensitivity of anthracyclines in multidrug resistant K562 cells. Eur. J. Biochem., 268: 4459-4467. DOI: 10.1111/j.1742-4658.2008.06488.x.

16. Laochariyakul, P., M. Ponglikitmongkol and S. Mankhetkorn, 2003. Functional study of intracellular P-gp-and MRP1-mediated pumping of free cytosolic pirarubicin into acidic organelles in intrinsic resistant SiHa cells. Can. J. Physiol. Pharm., 81: 790-799. PMID: 12897808. 
17. Patz, E.F., Jr., J.J. Erasmus, H.P. McAdams, J.E. Connolly, E.M. Marom, P.C. Goodman, R.A. Leder, M.T. Keogan and J.E. Herndon, 1999. Lung cancer staging and management: Comparison of contrast-enhanced and non-enhanced helical CT of thorax. Radiology, 212: 56-60. PMID: 10405720.

18. Morgunov, N.S., S.G. Foster and D.J. Hirsch, 1997. Contrast media induced changes in tubular electrophysiology and glomerular filtration rate in mouse kidney. Can. J. Physiol. Pharm., 75: 988-995. PMID: 9360013

19. Soejima, K., J. Uozumi, T. Kanou, C. Fujiyama and Z. Masaki, 2003. Nonionic contrast media are less nephrotoxic than ionic contrast media to rat renal cortical slices. Toxicol. Lett., 143: 17-25. DOI: 10.1016/SO378-4274(03)00091-2.

20. Broxterman, H.J., H.M. Pinedo, C.M. Kuiper, G.J. Schuurhuis and J. Lankelma, 1989. Glycolysis in P-Glycoprotein-overexpressing human tumor cell lines: Effects of resistance-modifying agents. FEBS. Lett., 247: 405-410. PMID: 2565823.

21. Salvioli, S., A. Ardizzoni, C. Franceschi and A. Cossarizza, 1997. JC-1, but not DiOC6 (3) or rhodamine 123 , is a reliable fluorescent probe to assess delta psi changes in intact cells: Implications for studies on mitochondrial functionality during apoptosis. FEBS. Lett., 411: 77-82. PMID: 9247146.
22. Zuliani, T., R. Duval, C. Jayat, S. Schnébert, P. André, M. Dumas and M.H. Ratinaud, 2003. Sensitive and reliable JC-1 and TOTO-3 double staining to assess mitochondrial transmembrane potential and plasma membrane integrity: Interest for cell death investigations. Cytom. Part. A, 54: 100-8. PMID: 12879456.

23. Backus, M., D. Piwnica-Worms, D. Hockett, J. Kronauge, M. Lieberman, P. Ingram and A. LeFurgey, 1993. Microprobe analysis of TcMIBI in heart cells: Calculation of mitochondrial membrane potential. Am. J. Physiol., 265: 178187. PMID: 8338127.

24. Dobrota, M., C.J. Powell, E. Holtz, A. Wallin and H. Vik, 1995. Biochemical and morphological effects of contrast media on the kidney. Acta Radiol., 399: 196-203. PMID:8610515.

25. Tervahartiala, P., L. Kivisaari, R. Kivisaari, T. Vehmas and I. Virtanen, 1997. Structural changes in the renal proximal tubular cells induced by iodinated contrast media. Nephron, 76: 96-102. PMID:9171307. 